\title{
Blastomycosis presenting as multiple splenic abscesses: Case report and review of the literature
}

\author{
Sami Al-Nassar MD FRCSC ${ }^{1}$, Tracy MacNair MD FRCPC ${ }^{2}$, Jeremy Lipschitz MD FRCSC ${ }^{3}$, \\ Howard Greenberg MD FRCPC ${ }^{4}$, Elly Trepman MD ${ }^{5}$, Sate Hamza MD FRCPC ${ }^{6}$, John M Embil MD FRCPC 5,7
}

S Al-Nassar, T MacNair, J Lipschitz, et al. Blastomycosis presenting as multiple splenic abscesses: Case report and review of the literature. Can J Infect Dis Med Microbiol 2010;21(1):5356.

A 31-year-old Canadian Aboriginal man from northwestern Ontario presented with left upper quadrant pain and a tender left upper quadrant mass. Evaluation with a computed tomography scan showed multiple lesions within the spleen, a collection between the splenic tip and splenic flexure of the colon, and several small adrenal lesions. Computed tomographic-guided needle biopsy showed necrotizing granulomatous inflammation and multinucleated giant cells. Gomori's methenamine silver stain showed broad-based budding yeast consistent with Blastomyces dermatitidis. Abdominal symptoms resolved after two months of oral itraconazole. Multiple splenic abscesses are a rare presentation of blastomycosis and should be considered in the differential diagnosis of left upper quadrant abdominal pain in a patient with a history of travel or residence in a region endemic for $B$ dermatitidis.

Key Words: Abdominal pain; Blastomyces dermatitidis; Fungus; Spleen

\section{Une blastomycose prenant la forme de multiples abcès spléniques : Rapport de cas et analyse bibliographique}

$\mathrm{B}$ lastomycosis is an uncommon granulomatous infection caused by the thermally dimorphic fungus Blastomyces dermatitidis, which exists in the mycelial form in the soil of warm, moist, wooded areas that are rich in organic debris (1-6). Conidia are inhaled when the mycelia are disturbed. At body temperature, they convert to thick-walled budding yeast $(7,8)$. Hematogenous dissemination is presumed to result in extrapulmonary blastomycosis. Blastomycosis presents most commonly with pulmonary disease but may also present with skin lesions, abscesses or osteomyelitis, which may lead to misdiagnosis or delay in diagnosis. The endemic area for blastomycosis includes the Ohio and Mississippi river basins, the regions that border the Great Lakes and northwestern Ontario (Figure 1) (9).

Blastomycosis may have a variety of different clinical manifestations (10), of which the pulmonary manifestations are the most frequent $(11,12)$. There are a few reports of individuals presenting with splenomegaly and left upper quadrant discomfort as the initial manifestation, subsequently leading to a diagnosis of splenic abscess caused by B dermatitidis (13-17). We report a case of blastomycosis presenting with multiple splenic abscesses and review the previously published reports regarding this condition.
Un homme autochtone canadien de 31 ans du nord-ouest de l'Ontario a consulté en raison de douleurs au quadrant supérieur gauche et d'une masse sensible dans la même région. L'évaluation par tomodensitométrie a révélé de nombreuses lésions dans la rate, un épanchement entre le bout et l'angle du côlon et plusieurs petites lésions des surrénales. Une biopsie à l'aiguille orientée par tomodensitométrie a révélé une infection granulomateuse nécrosante et des cellules géantes multinucléées. La coloration à l'argentméthénamine de Gomori a circonscrit un bourgeonnement de levure à large base compatible avec un Blastomyces dermatitidis. Les symptômes abdominaux ont disparu après un traitement de deux mois à l'itraconazole par voie orale. De multiples abcès spléniques constituent une présentation rare de la blastomycose et devraient être envisagés dans le diagnostic différentiel de douleur du quadrant supérieur gauche abdominal chez un patient ayant déjà voyagé ou habité dans une région ou le $B$ dermatitidis est endémique.

${ }^{1}$ Department of Surgery, King Saud University, Riyadh, Saudi Arabia; ${ }^{2}$ Department of Radiology, Diagnostic Services, Boundary Trails Health Centre, Winkler; ${ }^{3}$ Department of Surgery; ${ }^{4}$ Department of Diagnostic Imaging; ${ }^{5}$ Department of Medical Microbiology; ${ }^{6}$ Department of Pathology; ${ }^{7}$ Section of Infectious Diseases, Department of Medicine, University of Manitoba, Winnipeg, Manitoba

Correspondence: Dr John M Embil, Health Sciences Centre, University of Manitoba, MS 673-820 Sherbrook Street, Winnipeg, Manitoba R3A 1R9. Telephone 204-787-4654, fax 204-787-4699, e-mail jembil@hsc.mb.ca 


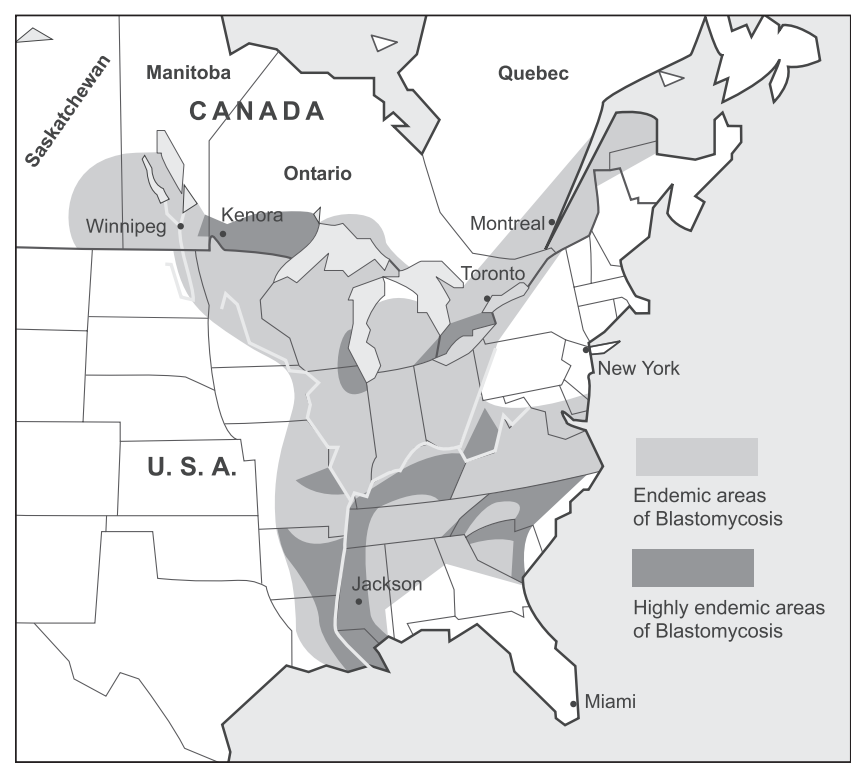

Figure 1) Geographical regions endemic for blastomycosis (modified from references 12 and 34). USA United States of America

complaints or night sweats. The patient also noted a $2.5 \mathrm{~cm}$ palpable mass in the midline of the neck, present for the previous two weeks. The patient reported that a chest radiograph two months earlier was normal.

Although a repeat CT scan was requested, the patient did not attend for the study until four months later. At this time, the CT scan revealed persistence of the splenic and adrenal lesions. A percutaneous needle biopsy of the spleen showed necrotizing granulomatous inflammation and multinucleated giant cells. Gomori's methenamine silver stain showed broad-based budding yeast consistent with $B$ dermatitidis (Figure 3 ). It was presumed that the neck mass was also due to blastomycosis.

The patient was treated with oral itraconazole $(200 \mathrm{mg}$ twice daily). He did not return for follow-up evaluation, but was successfully contacted six months after the biopsy. He stated that after two months of itraconazole, the left upper quadrant pain and the neck mass had completely resolved. He had independently discontinued the itraconazole after two months and did not return for further evaluation because of loss of insurance coverage as a result of marital separation. Further attempts to contact the patient were unsuccessful.

\section{DISCUSSION}

The current patient's presentation, with abdominal pain and splenic lesions, is an infrequently described manifestation of blastomycosis. He responded well to oral antifungal chemotherapy and did not require splenectomy.

All of the reported patients with splenic abscesses resulting from $B$ dermatitidis had contact with geographical regions endemic for $B$ dermatitidis (Table 1). The diagnosis of splenic abscess resulting from $B$ dermatitidis in previously reported cases involved varied radiographic investigations, including radionuclide investigations (Table 1). More recently, CT has led to a decreased need for radionuclide studies, and CT-guided splenic aspiration has facilitated biopsy, as in the present case, obviating the need for surgical intervention.

Several conditions, such as sickle cell hemoglobinopathy, nonpenetrating abdominal trauma, gastrointestinal malignancy,

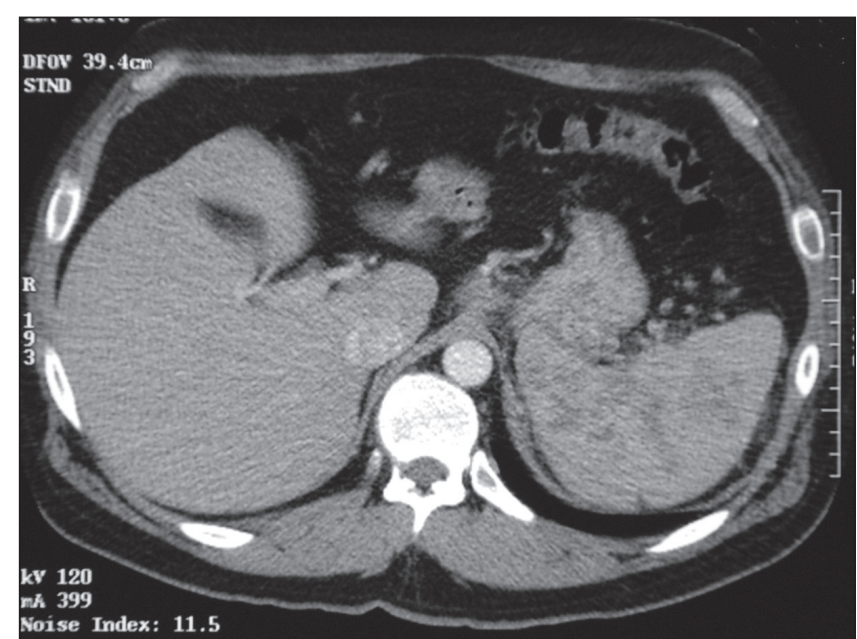

Figure 2) A contrast-enhanced computed axial tomographic scan of the abdomen revealing numerous tiny avascular low-density lesions that appear to be confluent

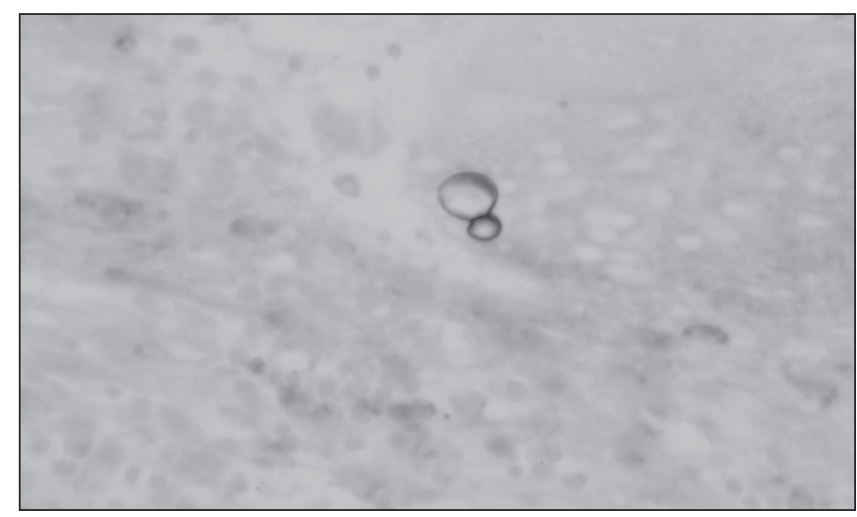

Figure 3) Microscopic evaluation of splenic biopsy tissue with Gomori's methenamine silver stain (original magnification $\times 400$ ) revealed broad-based budding yeast forms (diameter: $10 \mu \mathrm{m}$ to $20 \mathrm{\mu m}$ ) diagnostic of Blastomyces dermatitidis. The Ziehl-Nielsen stain (not shown) did not reveal acid-fast bacilli

infectious endocarditis and injection drug use may predispose to splenic abscesses (18-26). Circulating microorganisms may be filtered by the spleen, resulting in solitary and multiple abscesses. The spectrum of microorganisms recovered from chronic splenic abscesses is broad, including Staphylococcus aureus, streptococci, Enterobacteriaceae including Salmonella species, organisms of chronic infection such as Brucella species (27), anaerobes (Clostridium perfringens and Clostridium difficile), and other Gram-negative bacteria such as Burkholderia pseudomallei (28-31). The microbiology of splenic abscesses compiled from case series before 1986 noted the following breakdown of pathogens recovered from splenic abscesses: sterile 28\%, coliforms 23\%, streptococci 22\%, staphylococci $20 \%$, Salmonella species 11\%, anaerobic bacteria 5\% and fungi $1 \%$ (14).

In early reports, chronic abscesses were reported to be either sterile or caused exclusively by aerobic bacteria, but the spectrum of microorganisms reported from chronic abscesses has changed, likely as a consequence of improved microbiological techniques for the recovery of anaerobes and fungi and a heightened awareness that parasites may be responsible for 
TABLE 1

Cases of blastomycosis with splenic abscess

\begin{tabular}{|c|c|c|c|c|c|}
\hline & \multicolumn{5}{|c|}{ Case (reference) } \\
\hline & 13,14 & 15 & 16 & 17 & Current \\
\hline Age, years & 29 & 54 & 32 & 36 & 31 \\
\hline Sex & Male & Male & Male & Female & Male \\
\hline \multicolumn{6}{|l|}{ Ethnicity } \\
\hline Aboriginal & No & Yes & NR & NR & Yes \\
\hline African American & Yes & Yes & NR & NR & No \\
\hline Immunological risk factors & Injection drug abuse & Alcohol abuse & None & None & Alcohol abuse \\
\hline Pre-existing pulmonary disease & TB, pneumonia & TB & NR & NR & None \\
\hline \multicolumn{6}{|l|}{ Symptoms and signs* } \\
\hline Constitutional & Yes & Yes & Yes & No & No \\
\hline Weight loss (kg) & 10 & 5 & 30 & Yes (amount NR) & $\begin{array}{l}\text { None initially; } 18 \text { kg } \\
5 \text { months later }\end{array}$ \\
\hline Pulmonary & Yes & Yes & Yes & No & No \\
\hline Abdominal & Yes & Yes & Yes & Yes & Yes \\
\hline Musculoskeletal & No & Knee pain, effusion & No & No & No \\
\hline Presumed place of acquisition & Alabama, USA & Ontario & $\begin{array}{l}\text { Boston, USA/ } \\
\text { Eastern Canada }\end{array}$ & Minnesota, USA & Northwestern Ontario \\
\hline Presumed diagnosis & Not stated & Not stated & Hodgkin's disease & Not stated & Lymphoma \\
\hline \multicolumn{6}{|l|}{ Diagnostic studies $^{\dagger}$} \\
\hline Chest radiographic findings & Consolidation, pleural effusion & Pleural effusion & Normal & NR & Normal \\
\hline Ultrasonography & Yes & Yes & Yes & Yes (endoscopic) & No \\
\hline Abdominal CT scan & Yes & No & Yes & Yes & Yes \\
\hline Radionuclide scan & Yes & No & No & No & No \\
\hline Fine-needle aspiration & No & No & Yes & Yes & Yes \\
\hline \multicolumn{6}{|l|}{ Management } \\
\hline Splenectomy & Yes & Attempted ${ }^{\ddagger}$ & No & NR & No \\
\hline Antifungal chemotherapy & Yes & $\begin{array}{l}\text { Ketoconazole, } \\
5 \text { to } 6 \text { months }\end{array}$ & Yes & NR & $\begin{array}{l}\text { Itraconazole, } \\
2 \text { months }\end{array}$ \\
\hline
\end{tabular}

*Constitutional: night sweats, fever, chills, malaise and/or fatigue; Pulmonary: thoracic pain, decreased air entry or cough; Abdominal: pain, tenderness, guarding and/or palpable splenomegaly; ${ }^{\dagger}$ Ultrasonographic findings included splenic enlargement, hyper- or hypoechogenicity, and cysts; Abdominal computed tomography (CT) scan findings included splenic enlargement and low-density lesions replacing parenchyma; Radionuclide scanning in one case included a gallium 67 scan (photopenia in spleen) and technetium 99m sulfur colloid scan (splenomegaly and photopenia); Fine-needle aspiration in both cases done was diagnostic of blastomycosis; ' Laparotomy showed ascites; splenectomy could not be done because of dense adhesions. NR Not reported; TB Reactive tuberculin test

splenic abscesses (18-32). The apparent increase in reports of fungi, mainly Candida species isolated from splenic abscesses, may be a result of intensified chemotherapy and corticosteroid regimens for patients with neoplasms and inflammatory conditions requiring immunosuppression. Abscesses from parasites and other unusual microorganisms such as Nocardia species and mycobacteria have also been reported, attributed to immunosuppression, injection drug use and HIV infection (23).

The patient presented in the spring after having reported two months of symptoms. The time of presentation and clinical manifestations are compatible with previous studies reporting a seasonal variation of blastomycosis (33). Localized pneumonias typically present one to six months after initial exposure, with the presumed exposure occurring in the summer months. Four to nine months after the primary exposure, reactivation or slow progression of asymptomatic infection resulting in isolated extrapulmonary or disseminated hematogenous disease is observed. Our patient's presentation is compatible with these time lines (33).

Although rare, splenic abscess caused by B dermatitidis should be considered in an individual with left upper quadrant abdominal pain who has a history of travel or residence in a region endemic for $B$ dermatitidis. With CT scanning, CT-guided biopsy, ultrasonography and antifungal chemotherapy, splenectomy may be avoided in some cases (14-15).
The present patient was lost to follow-up, but if possible, patients should be followed because of the potential for chronicity or recurrence.

ACKNOWLEDGEMENTS: The authors thank Ms Carolyn Garlinski, Infection Prevention and Control Unit, Health Sciences Centre, Winnipeg, Manitoba, for secretarial assistance and Dr Zhaolin $\mathrm{Xu}$, Department of Pathology, Dalhousie University, Halifax, Nova Scotia, for reviewing the histology.

DISCLOSURE: There is no financial support or proprietary interest to report.

\section{REFERENCES}

1. Denton JF, McDonough ES, Ajello L, Ausherman RJ. Isolation of Blastomyces dermatitidis from soil. Science 1961;133:1126-7.

2. Denton JF, DiSalvo AF. Isolation of Blastomyces dermatitidis from natural sites at Augusta, Georgia. Am J Trop Med Hyg 1964;13:716-22.

3. Denton JF, DiSalvo AF. Additional isolations of Blastomyces dermatitidis from natural sites. Am J Trop Med Hyg 1979;28:697-700.

4. Sarosi GA, Serstock DS. Isolation of Blastomyces dermatitidis from pigeon manure. Am Rev Resp Dis 1976;114:1179-83.

5. Bakerspigel A, Kane J, Schaus D. Isolation of Blastomyces dermatitidis from an earthen floor in southwestern Ontario, Canada. J Clin Microbiol 1986;24:890-1.

6. Dixon DM, Shadomy HJ, Shadomy S. In vitro growth and sporulation of Blastomyces dermatitidis on woody plant material. Mycologia 1977;69:1193-5. 
7. Crampton TL, Light RB, Berg GM, et al. Epidemiology and clinical spectrum of blastomycosis diagnosed at Manitoba hospitals. Clin Infect Dis 2002;34:1310-6.

8. Medoff G, Painter A, Kobayashi GS. Mycelial- to yeast-phase transitions of the dimorphic fungi Blastomyces dermatitidis and Paracoccidiodes brasiliensis. J Bacteriol 1987;169:4055-60.

9. Schwarz J, Baum GL. Blastomycosis. Am J Clin Pathol 1951;21:999-1029.

10. Clinton TS, Timko AL Cutaneous blastomycosis without evidence of pulmonary involvement. Mil Med 2003;168:651-3.

11. Chapman SW, Lin AC, Hendricks KA, et al. Endemic blastomycosis in Mississippi: Epidemiological and clinical studies. Semin Respir Infect 1997;12:219-28.

12. Chapman SW. Blastomyces dermatitidis. In: Mandell GL, Bennett JE, Dolin R,eds. Bennett's Principles and Practice of Infectious Diseases. 6th edn. Philadelphia: Elsevier Churchill Livingstone, 2005:3026-40.

13. Dubuisson RL, Jones TB. Splenic abscess due to blastomycosis: Scintigraphic, sonographic, and CT evaluation. AJR Am J Roentgenol 1983;140:66-8.

14. Walker GT, McRoyan DK, Luterman A, Dowling EA, Curreri PW. Splenic abscess caused by Blastomyces dermatitidis. South Med J 1986;79:773-6.

15. MacDonald HJ, Fong IW, Gardiner GW, Soutter DI. Splenic abscess caused by Blastomyces dermatitidis in association with peritoneal involvement: Case report and review. Clin Infect Dis 1992;14:348-9.

16. Montes MA, DiNisco S, Dry S, Galvanek E. Fine needle aspiration cytology of primary isolated splenic Blastomyces dermatitidis. A case report. Acta Cytol 1998;42:396-8.

17. Deutsch JC, Burke TL, Nelson TC. Pancreatic and splenic blastomycosis in an immune-competent woman diagnosed by endoscopic ultrasonography-guided fine-needle aspiration. Endoscopy 2007;39:E272-E273.

18. Chulay JD, Lankerani MR. Splenic abscess. Report of 10 cases and review of the literature. Am J Med 1976;61:513-22.

19. Chun CH, Raff MJ, Contreras L, et al. Splenic abscess. Medicine (Baltimore) 1980;59:50-65.
20. Gangahar DM, Delany HM. Intrasplenic abscess: Two case reports and review of the literature. Am Surg 1981;47:488-91.

21. Nelken N, Ignatius J, Skinner M, Christensen N. Changing clinical spectrum of splenic abscess. A multicenter study and review of the literature. Am J Surg 1987;154:27-34.

22. Paris S, Weiss SM, Ayers WH, Clarke LE. Splenic abscess. Am Surg 1994;60:358-61.

23. Phillips GS, Radosevich MD, Lipsett PA. Splenic abscess: Another look at an old disease. Arch Surg 1997;132:1331-6.

24. de Bree E, Tsiftsis D, Christodoulakis M, Harocopos G, Schoretsanitis G, Melissas J. Splenic abscess: A diagnostic and therapeutic challenge. Acta Chir Belg 1998;98:199-202.

25. Green BT. Splenic abscess: Report of six cases and review of the literature. Am Surg 2001;67:80-5.

26. Toevs CC, Beilman GJ. Splenic abscess 10 years after splenic trauma: A case report. Am Surg 2000;66:204-5.

27. Vallejo JG, Stevens AM, Dutton RV, Kaplan SL. Hepatosplenic abscesses due to Brucella melitensis: Report of a case involving a child and review of the literature. Clin Infect Dis 1996;22:485-9.

28. Losanoff JE, Kjossev KT. Re: Splenic abscess: Report of six cases and review of the literature. Am Surg 2001;67:1014-5.

29. Gadacz T, Way LW, Dunphy JE. Changing clinical spectrum of splenic abscess. Am J Surg 1974;128:182-7.

30. Jacobs A, Barnard K, Fishel R, Gradon JD. Extracolonic manifestations of Clostridium difficile infections. Presentation of 2 cases and review of the literature. Medicine (Baltimore) 2001;80:88-101.

31. White NJ. Melioidosis. Lancet 2003;361:1715-22.

32. Wang TK, Chiu W, Chim S, Chan TM, Wong SS, Ho PL. Disseminated Ochroconis gallopavum infection in a renal transplant recipient: The first reported case and a review of the literature. Clin Nephrol 2003;60:415-23.

33. Light RB, Kralt D, Embil JM, et al. Seasonal variations in the clinical presentation of pulmonary and extrapulmonary blastomycosis. Med Mycol 2008;46:835-4.

34. Vallabh V, Martin T, Conly JM. Blastomycosis in Saskatchewan. West J Med 1988;148:460-2. 


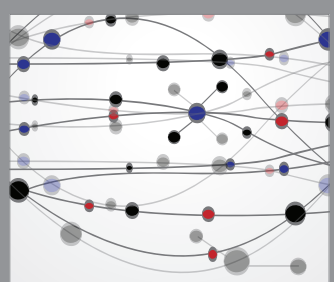

The Scientific World Journal
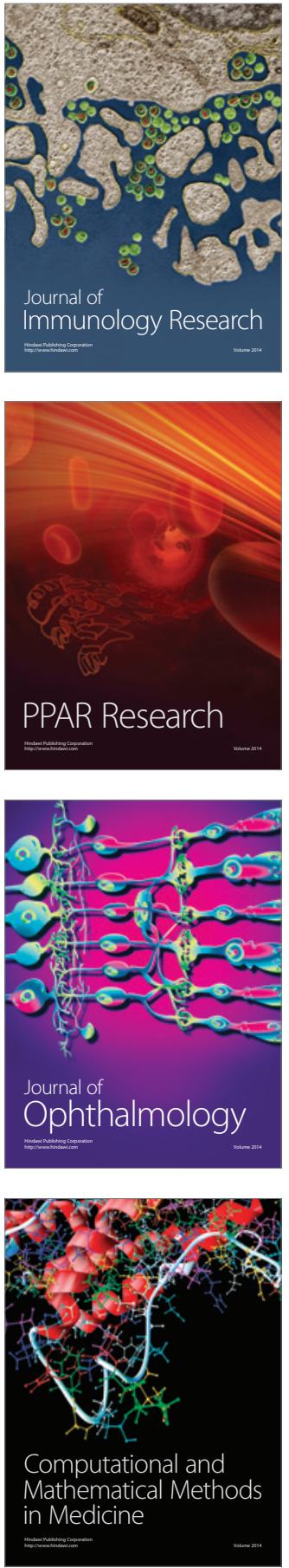

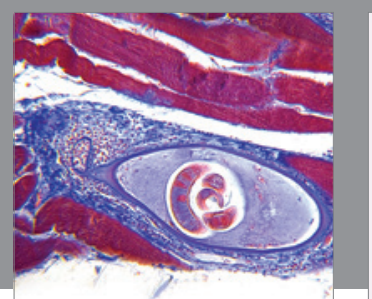

Gastroenterology Research and Practice

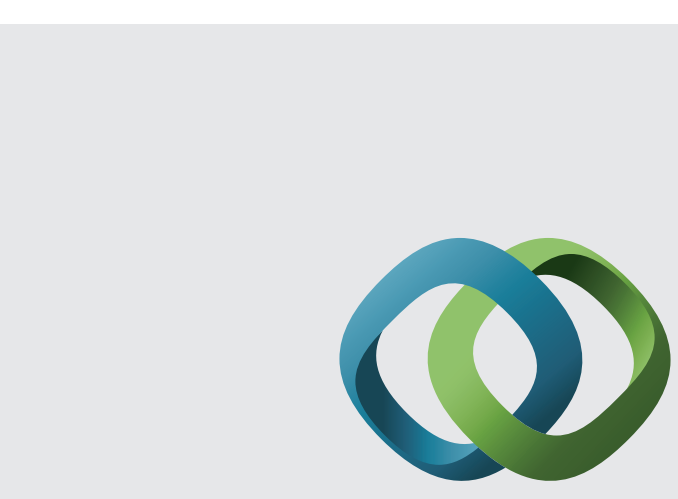

\section{Hindawi}

Submit your manuscripts at

http://www.hindawi.com
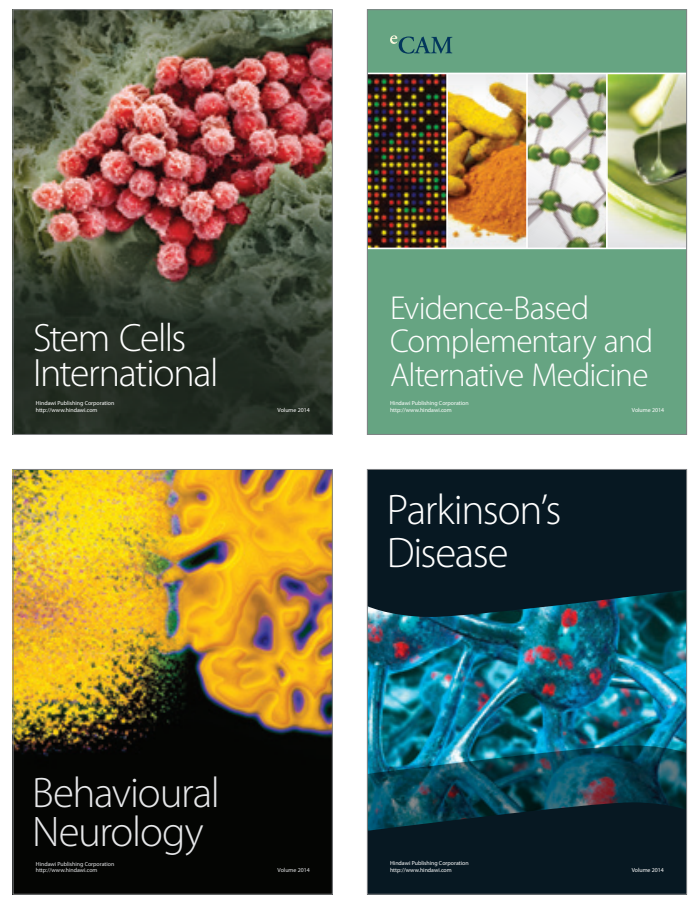
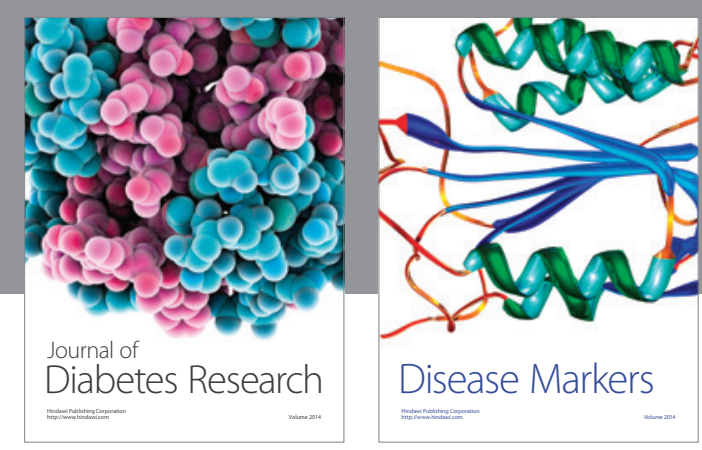

Disease Markers
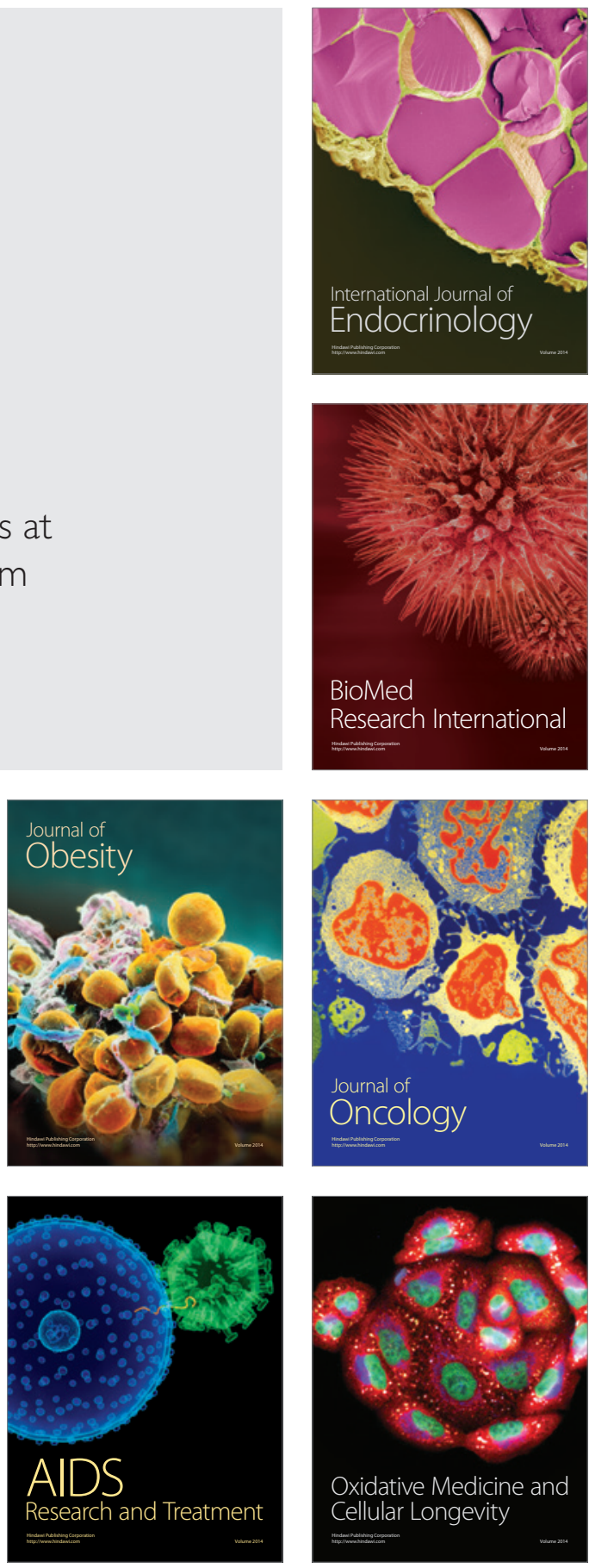